\title{
INDUSTRIAL RESTRUCTURING AND PROFESSIONAL QUALIFICATION REQUIREMENTS
}

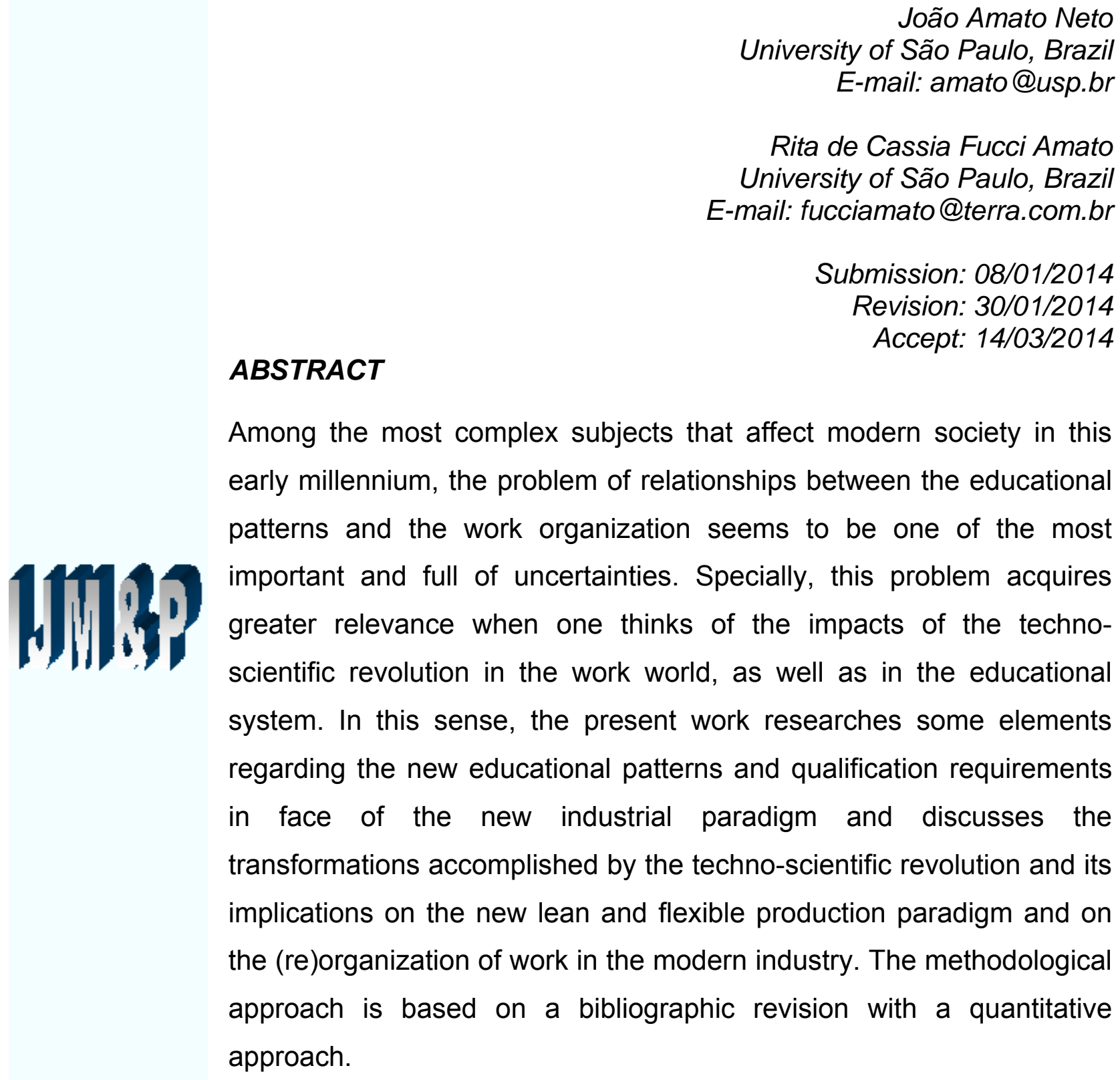

Keywords: Work organization, industrial restructuring, techno-scientific revolution, qualification requirements. 


\section{INTRODUCTION}

The globalization movement in course in the current economy has imposed new concepts and new ways of thinking the productive organization for the policy makers, specially in the nearly developed countries. These concepts are mainly related to the microeconomic level, such as: new types of organizational structures based on leaner and more flexible structures and supported by new technologies based on microelectronics; new work organizational principles and arrangements in the work organization, prioritizing multifunctional professionals group work; new productive arrangement models, besides other concepts and applications.

The transition from the mass production paradigm (Taylorist/ Fordist) to the flexible specialization one (WOMACK; JONES; ROOS, 1992; GOLDMAN; NAGEL; PREISS, 1995; GORANSON, 1995) has been provoking a series of new demands in terms of re-organizational structure, managerial behavior and new forms of operational work organization. Particularly, the emergence of new technologies based on microelectronics (the third industrial revolution) has represented a great potential for wide and deep transformations in the modern society. In fact, this transition represents a marked change in technological paradigm with deep social, economic and cultural impacts.

The impacts of those new productive configurations in the (re)organization of the work in the contemporary industry constitutes an aspect of great relevance for the understanding of the worker's new roles and the impacts of the new microelectronic equipment on the productive system.

In that way, the present article intends to understand those transformations historically occurring in the productive system, also aiming at its deficiencies and some answers to the questions posed before the contemporary production model.

Particularly, the new tendencies of the modern economic systems imply enhancing the incorporation of innovations deriving from techno-science. However, this phenomenon should be understood within the scientific magnitude referred to by Braverman (1981, p. 146):

The technical-scientific revolution, for that reason, cannot be understood in terms of specific innovations - as in the case of the Industrial Revolution, which can be correctly characterized by a handful of basic inventions -, but it should be understood more in its totality as a production way in which 
DOI: 10.14807/ijmp.v5i3.185

science and exhaustive engineering investigations are integrated as part of a normal operation. The key innovation is not to be found in Chemistry, in Electronics, in automatic machinery, in aeronautics, in Nuclear Physics, or in any of the products of those scientific technologies, but mostly in the transformation of science itself into capital.

Therefore, under the perspective of finding out new elements that can serve as references for a new work organization, the recent innovations from the Scientific and Technological environment are to be considered. Such innovations represent many challenges to overcome the deep gap between the current school formation and the techno-scientific development. This paper tries to identify the main aspects involved in this issue.

One of these aspects refers to the contradictions between the growing work qualification needs and, on the other hand, to the growing disqualification rhythm caused by this techno-scientific revolution itself, as well said by Enguita (1989, p. 230):

The process of capitalist production presents contradictory perspectives concerning the qualification of the work force. On the one hand, it tends to its disqualification, since this decreases its cost and it sets the bases for its best control; on the other hand, it requires a multilateral formation that allows the worker to change tasks and work position either without additional costs or minimizing them.

\section{INDUSTRIAL RESTRUCTURING}

The transition from the feudal production system to the capitalism originated fast economic growth. With the economic division of the work, productivity was intensely increased and, in an even more intense way, with the incorporation of the technological innovations brought about by the industrial revolution, during the $18^{\text {th }}$. century and up to first third of the $19^{\text {th }}$. century.

In the late $19^{\text {th }}$. century, with the techno-scientific revolution, these production units (manufactures) became factories and, after that, the great seriate industry, where productivity started to be extremely incremented, even in its developed phase and live work became more and more subordinate to the great capital (BRAVERMAN, 1981, p. 140).

In the beginning of the modern industry, some characteristics of the production systems were very outstanding: the operations were done in small scale and, as a consequence, the processes were easily supervised and controlled; there were little routine tasks, a lot of improvisation and, in consequence of this whole set, there were 
DOI: 10.14807/ijmp.v5i3.185

ample conditions for the accomplishment of innovations, even through the trial-anderror process.

With the growing expansion of the seriate production industry and already under the Taylorist-Fordist production paradigm, the production units started to present other characteristics: the growing need for generating scale economy imposed the tendency of great heavy industries and the increase in the rationalization and specialization of work, according to the precepts of the 'scientific administration' proposed by the engineer Frederic Taylor in the beginning of the $20^{\text {th }}$ century. The standardization of products and component parts of the products formed an alliance with Henry Ford's assembly line conception, complementing the mass production paradigm. Such paradigm prevailed practically along more than half of last century.

In that context, the great productive organizations were confronted with the need of establishing a group of norms, regulations and procedures, in order to better coordinate their activities, also creating departments and/ or sections specialized in that coordination. This is when a group of principles and of administrative functions that would compose the so-called "Classical Management School" is established, inspired mainly by Henri Fayol's ideas.

The productive organization of the beginning of mass industrialization underwent the bureaucratization phase, which in the conception of Weber (1981) is based on the existence of three elements that define the "ideal type of bureaucracy": formality, impersonality and professionalism. A bureaucratic organization, in the Weberian sense, should be understood as a structured organization, in terms of well documented regulations and procedures, in that the personal relationships are marked by the impersonality and professionalism (WEBER, 1981). Besides, bureaucracy is placed in a phase or stage of apprenticeship of the very development process of the industrial organizations.

Starting from the 1970s, a group of structural transformations can be verified in the capitalist production systems, that is particularly manifested by the new technological base of the productive units through automation, robotics and of the most different applications of the microelectronic revolution, with significant implications in the relationships and in the forms of work organization. 
Under the perspective of Piore and Sabel (1984), a new production paradigm appears, flexible specialization, known "as a new productive form that it articulates, on the one hand, a significant technological development and, on the other hand, a productive decentralization based on medium-sized and small companies, craftwork' ones" (ANTUNES, 1997, p. 17).

In the industrial production organization, the largest impacts were caused by the toyotism, or the Japanese model, that operationalized a technical revolution in the Japanese industry. Coriat (mentioned by ANTUNES, 1997, p. 23-24), points out four phases that determined the advent of toyotism:

First: the introduction, in the Japanese automotive industry, of the experience in the textile sector, given by the worker's need to simultaneously operate several machines. Second: the need of the company to answer to the financial crisis, increasing production without increasing the number of workers. Third: the import of management techniques from the USA, that created the kanban system. According to the terms attributed to Toyoda, Toyota president founder, "the ideal would be to only produce the necessary and to do it in the best time", basing on the supermarkets model, of replacing the products only after the sale. [...] Fourth phase: expansion of the kanban method for subcontracted companies and suppliers.

As from the third industrial revolution in the postwar and with the advent of the microelectronics technological paradigm and the flexible production systems, deriving from the experience in the Japanese industry (Toyotism), the productive organizations, after having reached a certain size and presenting certain complexity in their operations in the peak of the mass production paradigm, started to be confronted with the need of readapting to flexibility, and of recovering their innovative capacity. This is when the most flexible productive and organizational systems gain relevance, presenting lean production and agile manufacturing.

In that great transformations context in the productive structure, another important issue from the work point of view relates to the so-called "polyvalent" Japanese worker, which can be identified with the individual's capacity to operate several machines, combining several simple tasks.

Under this perspective of versatile worker and flexible productive system, Gorz (apud ANTUNES, 1997) presented the example of Volvo (Uddevalla, Sweden), where workers of that industry are organized in teams, taking the entire responsibility for the vehicle production process (from assembly to finishing). The members of that team, detaining the knowledge of the different techniques used, in spite of playing an 
DOI: 10.14807/ijmp.v5i3.185

important role in the productive process, do not play the main role, which belongs to the robotized production means.

Concerning the relationship between capital and work, Frank Annunziato, mentioned by Antunes (1997, p. 37), makes a critical evaluation of the Japanese model: "The Japanese capitalist, as a re-incarnation of the feudal lord, guarantees employment stability, obtaining, in turn, the feudal servant re-incarnation of loyalty and obedience from the workers".

\section{THE IMPACTS THE NEW MICROELECTRONIC-BASE EQUIPMENT AND THE (RE)ORGANIZATION OF WORK}

It is possible to say that the new microelectronic paradigm can be understood, from an eminently technical point of view, as the solution to the problems of capturing, negotiating, transmitting and receiving information, using integrated circuits (ERBER, 1977).

Thus, this new technical base, for constituting a revolutionary innovation, opens unique perspectives for the modern society and specially for the economy. Freeman (1987) emphasizes this revolutionary aspect of the microelectronics because this technology increases the appearance of new products and services, besides the fact that there is an enormous possibility of "pervasiveness" of this new technology for several economic sectors, implying significant alterations in the costs and input structures, as well as production and distribution conditions of goods and services.

Analyzing the main characteristics of this new technical-economic paradigm, based on microelectronics, Perez (1985) points out a series of advantages that this productive configuration facilitates, especially at the level of production systems of the information-intensive type, whose companies act, as a rule, in the most modern and dynamic economic sectors. It is possible to detach the following advantages among others:

- The minimization of energy and materials consumption in the different production processes;

- The obtainment of high precision levels and, consequently, the possibility to produce with narrow tolerance margins; 
DOI: 10.14807/ijmp.v5i3.185

- Larger control of stocks and inventories;

- Better quality control in line, which consequently allows a significant reduction in wastes and refuse indexes and of reworks;

- Finally, and as a direct consequence of the other items, the new paradigm facilitates a considerable increase in resource productivity.

As suggested by Coriat (1988), the microelectronic equipment can be classified in four different categories, in agreement with its functions in the productive process:

1) Operation means: machines endowed with tools and that execute a production program, which is translated into a sequence of operations, as, for example, milling, welding, painting, manipulating and transporting pieces, etc. In this category one can already find the well-known industrial robots, machine-tool with computerized numerical command and the milling centers;

2) Materials manipulation and feeding means: machines that just transfer pieces from a work post to another one, executing tasks such as piling up, storing and packing. As an example, the "automated" trolley can be mentioned.

3) Programmable computing and control means for equipment: machines used in the production flow, for information reception and control. They are properly represented by computers (mainframe, mini and personal computer), numerical command, logical-programmable controllers etc.

4) Project aid means: equipment that allows for fast and simple obtention of a three-dimensional design of the parts to be manufactured. The most widely known example is "CAP" - Computer Aided Project", which can also be coupled to the operation means to form "CAM-CAP" - and Computer Aided Manufacture and Project".

Under the essentially technological point of view, the great novelty of these pieces of equipment is that they can be quickly scheduled and re-scheduled, since the computerized controllers of the equipment make its operations by means of sensors, and they are capable of activating the operation program corresponding to the part to be automatically produced. The different models of equipment can be used in a combined way or separately, in the context of "arrangements", integrated 
DOI: 10.14807/ijmp.v5i3.185

by multiple equipment and relationships among them, as commented by Coriat (1988).

Besides, these pieces of equipment are compatible with information and communication systems and subsystems, which makes their application potential practically limitless in the process of industrial production. The coming of the global nets of telecommunication (Internet, especially), under the support of the so-called digital economy, in a general way has largely influenced the companies' strategies and those of manufacturing in particular, also pointing to the organizations and virtual companies concept (SCHUH, MILLARG and GORANSSON, 1998), understood as dynamic nets of inter-organizational cooperation, that strengthen the generation of a series of new business opportunities for the partners belonging to a specific value net.

In this sense, all of the operations referring to production, marketing, logistics, product project, research and development, material supply, engineering, etc., can be strongly increased through the intensive use of the new information and communication technologies - ICTs.

As from what it was previously analyzed, the development of microelectronics technology and of computer science is made clear, represented by the computer and other "intelligent components", which allow for a new reality for the work world, as verified by Lyon (1992, p. 73):

three popularized images of work in the 'information era': The first is that of robotized assembly line [...] The second image is the one of the new industrial relationships. [...] Going to the third image, one comes across the implicit promise of renewed relationships, now in the "electronic dwelling place". This sentence, popularized by Alvin Toffler, marks a phenomenon that is effectively confronting a growth fostered by technology: work at home.

An aspect very discussed as from this new reality refers to the fact that the new microelectronic technologies (in their different application spheres within a company) are work-saving. In fact, the introduction of these technologies, associated to the new forms of work organization in production, destroys jobs at an increasingly growing pace. This fact is highlighted in the different authors' vision: for Lyon (1992), there is a clear correlation between the progress of the new microelectronic 
technologies (represented, especially, by the chip) and the global loss of workplaces in the advanced economies.

For Peña Castro (1994), however, the confluence of these new technologies with the new methods of managerial administration brings negative consequences for most of the workers, because it is a labor-saving technology that destroys jobs and it reinforces the submission of work in relation to capital.

The computer science and the telecommunications revolution allowed for a new model of distribution of the industrial facilities and, consequently, of the size of the industrial grouping. In this context, the change of technological paradigm propitiated by the development of microelectronics started to create a new productive strategy, through the substitution of conventional, specialized machines and dedicated to a single operation, for programmable machines of multiple objectives. In this sense, the production of goods and services started to acquire a new sense: instead of the old production style of great volumes and limited variety of standardized products, we verified a new reality: the production of a wide variety of small lots of differentiated products.

Consequently, the whole change in process of the production paradigm also brought significant implications for the work issue (organization forms, relationships with capital, work conditions, etc.), as well as having widely influenced the managerial style in the companies, which now value more participative forms and work organization in more autonomous teams.

From the work point of view, its nature and its organization in the company, new concepts and proposals are already presented as an irreversible tendency. This way, the narrow conception of work based in the so-called scientific administration of Taylor (who emphasized specific training and narrow worker's qualification, clear separation between conception and execution of routine tasks) has given way to the emergence of new work organization arrangements, where there is a quest to conjugate integration values between work conception and execution, broad qualification and training, cooperation in team work, larger autonomy in decisiontaking, among other values despised by that current of administrative thought from the beginning of the $20^{\text {th }}$ century. 
DOI: 10.14807/ijmp.v5i3.185

Finally, another series of institutional changes accompanies those introduced in the productive system, fundamentally implying a deep revision of the very nature of the State and of its functions. This whole set of transformations points to the establishment of a new conception in the production of goods and services.

\section{THE NEW INDUSTRIAL PARADIGM AND WORK ORGANIZATION}

The signs of the new patterns in the modern industry (or of a new industrial production paradigm) can already be detected as from the postwar period and, specially, as from the 1970s, when the world economy and the industrial production systems came across a new configuration, represented by the Japanese production system as the most dynamic model. Such configuration implied deep changes in the traditional forms of industrial organization based on three basic elements, according to Hoffman and Kaplinsky (1988):

- New forms of work organization;

- Technological revolution with the emergence of new microelectronics-based technologies;

- New pattern of inter-relationship among companies.

Especially concerning the new forms of work organization that emerged as from the advent of the new paradigm of flexible and lean production, one particularly stands out as predominant within the most dynamic sections in the world economy. In this type of new work organization forms, already developed in the Japanese automotive and electronic companies for the last two or three decades, the basic objective is to promote a larger workers' involvement and commitment in the productive process.

\section{THE ISSUE OF PROFESSIONAL (RE)QUALIFICATION}

In this context of productive re-configuration resulting from the new industrial paradigm, the workers that remain employed after all the technical and organizational transformations get more demands concerning their abilities and qualifications. However, the issue of work qualification should be well posed from the very start.

For Peña Castro (1997), there has been a lot of debate on this dilemma (disqualification or re-qualification), without, however, reaching clearer conclusions regarding this subject. The same author points out, on the other hand, the need for a 
DOI: 10.14807/ijmp.v5i3.185

larger understanding regarding the very work qualification concept: "Actually, work qualification, far from being an evident datum, is a problematic, multicasual relationship whose study involves technical-economic, political and cultural dimensions" (PEÑA CASTRO, 1997, p. 1).

Referring to the problem that involves the qualification concept, sociology, willing to investigate the transformation occurring in the new technical-economic paradigm, finds fundamental methodological difficulties in the exercise of its investigations. For Monteiro Leite (1996), three methodological possibilities are posed to deal with the theme:

- The occupational analysis approach, dominant in the 1960s.

- The studies on work process, typical of the 1970s.

- The thesis on the social construction of competence, starting as from 1980.

In the first approach, the qualification defined essentially as human capital is adopted under the focus of occupational analysis (neoclassical extraction), being the worker mobilized in the work process, including theoretical and practical abilities, formal and informal knowledge. Qualification, in that sense, can be analyzed through the decomposition of the work position into a group of tasks, with possibilities to accomplish mensuration's and precise descriptions.

The second approach focuses on studies on work process and the qualification requirement is presented in two aspects: worker's knowledge and worker's autonomy. In that perspective, the focus of attention is "disqualification" and not qualification; therefore, technology is part of that process of production relationships, within the capitalist company, aiming to disqualify to control. Under that approach, the polarization of qualifications is also posed, resulting in small portion of super-qualified workers in opposition to an enormous mass of disqualified ones.

The thesis about the social construction of competence presents a new relative reading related to qualification, emphasizing concrete historical-social situations (product of the dialectical relationship capital-work). This trend understands the qualification as an articulation or relationship between heterogeneous domains. A new proposal is being defined in the amplification of the three focuses mentioned previously, establishing a new relationship between work and communication and, 
DOI: 10.14807/ijmp.v5i3.185

therefore, a new qualification conception as competence: it "is not so much the volume of knowledge that matters, but the domain capacity or conduction of unexpected situations - 'events' - and the recognition of that capacity" (MONTEIRO LEITE, 1996, p. 59).

Confronting the different elements of work and of the qualification demands, characteristic of the "old mass production paradigm", with the one of the "new flexible paradigm" or lean production paradigm, Monteiro Leite (1996) presents synthetic Table 1 as follows.

Table 1: Work and Qualification

\begin{tabular}{|c|c|c|}
\hline & MASS PRODUCTION & FLEXIBLE PARADIGM \\
\hline Economy & In expansion & Crisis \\
\hline Market & Stable & Unstable \\
\hline Competence & Local & World competence \\
\hline Salesperson & $\begin{array}{c}\text { "The company has the upper } \\
\text { hand" }\end{array}$ & "The customer is the king" \\
\hline Products & Standard & Diversified \\
\hline Product cycle of life & Long & Short \\
\hline Production system & Mass production & Small lots / Customer order \\
\hline Technological base & $\begin{array}{c}\text { dedicated machine (electro- } \\
\text { mechanical base) }\end{array}$ & $\begin{array}{c}\text { Multipurpose machines } \\
\text { (microelectronic base) }\end{array}$ \\
\hline Management structure & $\begin{array}{l}\text { Hierarchical organization } \\
\text { (centralized: "The boss is } \\
\text { always right") }\end{array}$ & $\begin{array}{c}\text { Horizontal structures } \\
\text { (participative management: } \\
\text { "Everybody is responsible") }\end{array}$ \\
\hline $\begin{array}{l}\text { Work tasks (operational } \\
\text { process) }\end{array}$ & $\begin{array}{c}\text { Divided / prescribed / } \\
\text { specialized }\end{array}$ & Integrated / aleatory / versatile \\
\hline Work control & Hetero-controlled & Self-management \\
\hline Qualification requirements & To know (how to do) & To learn \\
\hline Other work requirements & $\begin{array}{c}\text { Discipline / obedience / } \\
\text { memorization / observance of } \\
\text { norms / reaction / }\end{array}$ & $\begin{array}{c}\text { Initiative / administration of the } \\
\text { aleatory / reasoning / pro- } \\
\text { action }\end{array}$ \\
\hline $\begin{array}{c}\text { Other features of work } \\
\text { organization }\end{array}$ & Individual behavior / & Collective behavior \\
\hline
\end{tabular}

Source: Adapted from Monteiro Leite (1996, p. 69).

Actually, the demands for a larger level of professional qualification consist of a strong differentiation between the new productive paradigm and the Taylorist / Fordist one. In the current productive configuration, several abilities and competences are demanded; nowadays the worker has to think, to decide, to have initiative and responsibility, to manufacture and to repair, to manage production and the administration of the productive process, as pointed out by Hirata (1994).

Yet, in Torres (1995), the production reaches its apex when several aspects, such as a fair remuneration, the appropriate qualification and a strong motivational policy, interact in favor of the worker. Neves (mentioned by FRIGOTTO, 1995a) 
DOI: 10.14807/ijmp.v5i3.185

states that entrepreneurs are becoming aware that the low level of workers' qualification constitutes an obstacle before the new demands posed by the current pattern of production. On the other hand, Castro says (1994, p. 43):

To face the "technological vulnerability", capital rediscovered the work humanity of the worker that was ignored by Taylorism. Forced by the vulnerability and complexity of its techno-organizational base, capital got interested in the appropriation of the collective worker's socio-psychological qualities through the so called socio-technical team work systems, of the quality circles etc. These are new forms of managing the work force aiming to guarantee the integration of the worker with the company's goals.

In that new productive configuration, the versatile worker's privileged position stands out, that is to say, that of the ones capable of accomplishing multiple tasks. It is the case, for example, of a worker in a metallurgical sector company, who, having fundamental knowledge on milling, starts to operate different types of machines, such as lathes, milling machines, drills, overhaulers, etc. The idea of a versatile worker breaks, at least partly, with the old Taylorist conception of specialized work.

On the debate concerning the worker's formation, Machado (1994b) points to a versatile and polytechnic qualification conception. Versatile qualification allows a certain administration of time by the individual, not necessarily resulting in a qualitative change in the productive process. In that conception, what really stands out it is the empiric knowledge on the empirical ways of operating production. "As polytechnics is understood the mastery of a technique at an intellectual level and the possibility of flexible work with the re-composition of tasks at a creative level" (MACHADO, 1994b, p. 19). In that conception, what is sought is a worker with greater autonomy, who can develop by himself in the organization of his tasks.

In that sense, Salerno (1994a, 1994b) warns that one should distinguish between the "multifunctional" and the "multi-qualified" worker, who would be, strictly speaking, the versatile one. "Multifunctional" would be the industrial worker capable of dealing with more than one machine with similar characteristics and of accomplishing routine tasks of inspection and/ or maintenance, which would not be little in terms of professional progress. Nevertheless, the "multi-qualified" worker goes beyond, developing and incorporating different abilities and professional repertoires, including the planning of his own work.

The whole operations strategy in the companies, within this new paradigm of flexible production, has been guided by the permanent search for quality excellence 
DOI: 10.14807/ijmp.v5i3.185

by the whole company and of the "zero defects production" and "zero stocks". In this sense, programs like the "Circles of Quality Control - CQCs", "Total Quality Control TQC" (JURAN; GRYNA 1988; ISHIKAWA, 1986); "Just-in-time/ KANBAN" (SCHONBERGUER, 1986), the quality committees within the companies and the quality prizes (such as Deming in Japan, Malcom Baldridge in the United States and the National Quality Prize in Brazil) became symbols of a fake modernization of the productive systems (AMATO NETO; FUCCI AMATO, 2004). Relating the quality systems to worker's education, Guedes (1999) states that the Total Quality Control (TQC) programs, in the perspective of the individual's re-qualification, is translated into a pedagogical project of the company, with courses for qualifying and requalifying, faced with the innovations of the productive process and the administration patterns it has adopted.

It is worth pointing out that this whole form of work organization can be largely enhanced with the use of automatic equipment of microelectronic base, both in the operation and in the transportation of parts from one post to the next, although the use of that equipment does not constitute a pre-requisite for the implementation of those organizational changes.

\section{WORKER'S FORMS OF LEARNING}

Analyzing the qualification aspects relative to the teaching/ learning process in the late industrialized countries Fleury and Fleury (1995) present a typology of the different learning forms and technological capacitation from a revision of the recent literature on this subject.

The first category presented concerns learning by operating or learning by doing in which learning occurs at the same time as there are feedback processes from the very production activities. The second category approaches learning by changing, when the worker adapts to the operational changes that occur systematically within a given organization. System performance feedback, in turn, consists in situations in which learning depends on the existence of institutionalized mechanisms to generate, register, analyze and interpret pieces of information on the production performance. The possibility of accessing the organizational performance indicators would make such learning form viable. 
DOI: 10.14807/ijmp.v5i3.185

Another category presented by the authors is called learning through training, which consists in formal training, both in the technical and managerial aspects, commonly applied in great companies.

On the other hand, learning by hiring refers to the appropriation of knowledge and abilities by means of hiring professionals that transfer their expertise to the hiring work environment. Last but not least, learning by searching concern the learning forms deriving from technology transfer. It is worth stressing that, at the present development stage of information technology, this learning category emerges remarkably, once the learning process, both formal and informal goes on, develops with great possibilities for updating information and knowledge, mainly in the virtual communities.

For Machado (1994a), the knowledge of the operation methods, the capacity to adapt to innovations, to identify tendencies, to analyze and to solve problems, added to (oral, written and visual) communication abilities and to other experiences of an individual, to help in his performance in the productive process and in his continued learning, either by training or autonomously.

This shows that there is a replacement of the demand for professional formation directed to learning by doing by another formation that allows learning to learn. It is a new way of processing information, a new matrix to guide the efficiency and competence criteria and, therefore, the very qualification policy. (MACHADO, 1994a, p. 183)

Adapting to innovation demands the individual's intellectual development, allowing him to elaborate critical thinking and thus to more actively participate in the productive process. Under that perspective, the interdisciplinary is a distinguished factor in the worker's formation; the philosophical, scientific and historical knowledge allows a new view of the world and a wider application of the trinomial S,T\&I (Science, Technology and Innovation) to our day-to-day. Thus, the search for new knowledge allows a re-updating of the worker at all levels of society, reaching the ideal of citizenship (MACHADO, 1995; GENTILI, 1995). For Frigotto (1991, p. 12): "At the educational and technical qualification level, different studies point to training exhaustion and professional formation disconnected from basic formation".

According to Fartes (2000), as a counterpart to an ever increasing attempt to normalize work organization in the companies, there is a tendency to diversify formative spaces: generally the social environments (family, community, etc), the 
DOI: 10.14807/ijmp.v5i3.185

company (by means of courses and training), education and the experience attained along professional life are combined in the worker's formation.

Under the larger qualification perspective, here understood in its professionals' technological and managerial capacitation trend, the use of the several learning categories should be part of a consistent body of strategies ensuring a real competitiveness for the companies in the globalized markets, mainly in the cases of those operating in late industrialization economies.

Certainly this whole form of work organization can be widely enhanced with the use of automatic microelectronic equipment, both in the operation and in the transportation of parts from one post to the next, although the use of that equipment does not constitute a pre-requisite for the implementation of those organizational changes.

\section{PERSPECTIVES FOR DEVELOPING COUNTRIES: A COMPARISON BETWEEN SOUTH KOREA AND BRAZIL EDUCATIONAL RESOURCES}

One of the greatest challenges imposed to the late industrialization countries, concerning their self-sustainable development projects, refer to the new educational demands caused by the intense globalization process and productive restructuring, occurring more intensely in the last three decades. In this context, a brief historicaleconomic comparative analysis of Brazil and of South Korea it is pertinent, and can provide explanatory elements for clarifying this phenomenon.

The Korean industrial structure followed the format of great conglomerates of national capital - the chaebols (as the keiretsu in Japan) - which, supported by governmental banks integrating a governmental industrialization project, allowed a set of high profitability productive enterprises. Such conglomerates tried and motivated technologies transfer by means of Japanese companies and a structural change in the industrial base, using qualified labor and more intensive technology products. Such strategy allowed to the Korean companies to incorporate higher value-added to their products, facilitating their introduction in more demanding markets.

On the other hand, the Brazilian industry accomplished few technological progresses along this period (1970/ 2000), being the small incursions in electronic technology restricted to transnational companies or majority partnerships. The 
DOI: 10.14807/ijmp.v5i3.185

insertion of Brazil in the international market was basically due to low-cost and unqualified labor.

Regarding the professional qualification aspect, Korea accomplished an outstanding effort, concentrating high investments on the educational area (inspired by the Japanese model). This country introduces one of the highest education levels today among the nations of late industrialization; this fact decisively contributed to its strategy of entering the most sophisticated and intensive technology segments of the modern industry.

It should be pointed out that up to 1960, Brazil and South Korea were part of a group of nations going through their first phases of industrial development and presented a much lower socio-economic development than that of industrialized countries. The illiteracy rate in both countries was around 35\%; nevertheless, Brazil presented some differential from the economic point of view, with a per capita income practically twice as large as the Korean one.

It can be verified that Korea achieved a process of substantial economic development along the last 40 years, tripling the size of its economy every decade. Along this period, this Asian country practically eradicated illiteracy, while in Brazil there is still a $13 \%$ illiteracy rate and just $18 \%$ of youngsters enrolled in universities. Such parameters, in synthesis, reflect the attention the respective governments dedicated to the educational systems along this period. Contrary to the Korean option for qualified labor and a certain education level, in Brazil an industrialization process was verified that facilitated the workers' use with little or no education (in many cases with the predominance of the so called "functional illiterates"), consolidating a dichotomy between education and work. See table 2 below:

Table 2: Educational policies: a comparison

\begin{tabular}{|c|c|}
\hline Brazil & South Korea \\
\hline Lack of consistent public policies & Governmental Project \\
\hline Lack of public investments & Japanese investments \\
(Fiscal Government crisis) & Foreing debt reduction \\
\hline Commitment in paying foreign debts & Better income distribution \\
\hline Social gap & Large investments in education \\
\hline Deep educational needs &
\end{tabular}

Source: The authors', based on Posthuma (1996). 
DOI: 10.14807/ijmp.v5i3.185

Observing another aspect, it can also be verified that Brazil invests less than $1 \%$ of its GDP in Science, Technology and Innovation (S,T\&I) activities, far less than the industrialized countries' average and that of South Korea, which invests about $2.5 \%$ of its GDP. In terms of intellectual property, about 30 times less patents are registered in Brazil than in the USA and in Korea, also pointing out that more than $80 \%$ of these patents are not generated in Brazil. Unlike what happens in the developed countries and in South Korea, the Brazilian private sector employs less than $10 \%$ of doctors and invests less than $40 \%$ of the total resources directed to S,T\&I, according to FINEP and of IEA/ USP data, as mentioned by Crestana (2004).

Logically, the cultural differences among the two countries are to be noted, which requires a certain relativity degree in such comparisons. However, still considering such differences, it is possible to learn some lessons from the Korean experience, in order to reflect the challenges posed to the Brazilian development in the near future (VEJA, 2005).

Least but not least, we should notice that the patterns of economic development and their links to educational strategies have special contexts and effects that make uneasy to design conclusive comparisons. Considering the possibilities of generalization and comparison of the Brazilian 'model' of development, Celso Furtado (1973, p. 77) wrote: "India never will be a Sweden of a billion people, neither Brazil will be a reproduction of the United States" - or South Corea, we should include. Furtado (1993, pp. 77-9) also pointed out that the developmental paths incur in social costs as so as social requirements and improvements. In this context, the Brazilian social gap was not only an obstacle but even an inner constraint upon which its historical paths of dynamic centers and dependent ones were framed. By the other side, a model drived by an autocratic State as the South Corean one generated possibilities for comprehensive projects and partnerships that were not present even in the autocratic periods of Brazilian government (SANTOS FILHO, 1991). And a democratic pattern of industrial and educational policy has to solve similar problems in a different way.

\section{FINAL CONSIDERATIONS}

Within the context of the techno-scientific revolution and with the transition of the industrial restructuring process, the new quality and productivity concepts, the 
DOI: 10.14807/ijmp.v5i3.185

professional competence, as well as the workers' and companies' learning capacity in general constitute one of the main factors that will differentiate the organizations in the inter-capitalist competition process in the globalized world.

The recovery of qualification, here understood as the transcendence and valorization of the workers' professional competence, also encompasses a dimension of citizen's rights, going beyond the very company walls: to read, to interpret reality, to verbally and in written express and to manipulate abstract scientific and mathematical concepts, to work in group for solving specific problems of a sector or workplace, among other aspects, are posed as fundamental requirements for living in modern society.

All those angles approached demand the recovery of education in its technical-pedagogical and organizational dimensions. A new association is imposed onto the different social agents: Governments, companies, workers, schools. In this sense, education particularly has a decisive role in this intense and deep changes process, a role that demands urgent (re)definition in order to provide subsidies so that, in these first years of the third millennium, mankind finds a new logic in the understanding of concepts about itself, about the world and about the what mankind's role is in the world.

Undoubtedly, the trinomial Science, Technology and Innovation (ST\&I), in its more visible perspective, that is, that of industrialization, will innovate human activities in all the sectors and, more and more, only through Education can the ethical questionings of the ST\&I development process be approached and of their imbricate infiltrations. Only by Education will life quality, the quest for citizenship, for the leveling of social inequalities, for dignity and for human happiness be preserved and prioritized.

Specifically, in the case of Brazil, there is, on the one hand, a series of restrictions to sustainable development, added to a huge socio-economic and cultural debt historically accumulated all along its lifetime. Besides the political-institutional hindrances, that still stall a better agility by the Brazilian Government in taking decisions concerning the several reform fronts (fiscal, administrative, welfare, agrarian, etc), there are also - even as a consequence of the previous ones - more specific hindrances concerning, for example, the precariousness and the 
obsolescence of the transportation and telecommunication infrastructures, directly affecting the operational performance of the companies. The impacts of this scenario on the work world have been severely worrying. Added to circumstantial chronic unemployment in the Brazilian economy, there is also a structural unemployment component (technological one), more intensely manifested in the more modern sectors of economy, where the third industrial revolution has penetrated more intensely: the automotive industry, the electro-electronic industry and the banking sector, for instance.

On the other hand, many other opportunities open up for the Brazilian economy, for its being an emergent economy, with a great potential for a consumer market of approximately 180 million inhabitants and with many consumption lacks in all aspects. The expectations of new direct investments on the part of great transnational groups, added to the expectations of a wide reform of the Brazilian Governmental structure and consequent public investments in the improvement of transportation and telecommunication infrastructure should provide a new scenario for new enterprises.

In the point of view of educational requirements for work, it has to be considered that, under the new industrial paradigm marked by the techno-scientific revolution, the demands for quickly disseminating up-to-date knowledge in a continuous way becomes a sine qua non condition for any sustainable development project, following what is already done by other recently industrialized countries.

It is also worth mentioning the new possibilities provided by information technologies, which can contribute to reorganizing the industrial production and for a new relationship with the market and with the workers (CHESNAIS, 1995). Within this context, opportunities generated by the virtual organizations and, mainly, by digital inclusion and telework (through the internet, for example). These are themes that deserve specific room for greater deepening and discussion, which can cause the elaboration of new investigations.

Within the context of techno-scientific revolution and industrial restructuring process, the quality and of productivity concepts, the professional competence quality and the workers' and the companies' learning capacity in general constitute 
DOI: 10.14807/ijmp.v5i3.185

one of the main factors that will differentiate the organizations in the process of intercapitalist competition in the globalized world.

All those angles approached demand the recovery of education in its technical-pedagogical and organizational dimensions. A new association is imposed on the different social agents: Governments, companies, workers, schools. In this sense, education particularly has a decisive role in this process of intense and deep change, a role that urgently needs (re)definition, in order to provide subsidies so that, in this early third millennium, mankind finds a new logic for understanding concepts about itself, about the world and about the role played by mankind in the world.

\section{REFERENCES}

AMATO NETO, J.; FUCCI AMATO, R. C. (2004) 'Trabalho e educação: novos desafios impostos pela tecnociência'. Trabalho e educação, Belo Horizonte, v. 13, n. 02, p. 177-188.

ANTUNES, R. (1997) Adeus ao trabalho? Ensaio sobre as metamorfoses e a centralidade do mundo do trabalho. São Paulo: Cortez; Campinas: Editora da UNICAMP.

BRAVERMAN, H. (1981) Trabalho e capital monopolista: a degradação do trabalho no século XX. Rio de Janeiro: Zahar Editores.

CHESNAIS, F. (1995) A globalização e o curso do capitalismo de fim de século. Economia e Sociedade, Campinas, n. 5, p. 1-30.

CORIAT, B. (1988) 'Automação programável: novas formas e conceitos de organização da produção'. In: SCHMITZ, H.; CARVALHO, R. Q. (Orgs.). Automação, competitividade e trabalho. São Paulo: Hucitec.

CRESTANA, S. (2004) Inovação e desenvolvimento: faces da mesma moeda. Revista Aprendizagem, Brasília.

ERBER, F. (1977) Technological development and state intervention: a study of the Brazilian capital goods industry. Sussex: The University of Sussex.

FARTES, V. L. B. (2002) Trabalhando e aprendendo: adquirindo qualificação em uma indústria de refino de petróleo. Educação e Sociedade, Campinas, n. 78, p. 225-254.

FERNÁNDEZ ENGUITA, M. (1989) A face oculta da escola: educação e trabalho no capitalismo. Porto Alegre: Artes Médicas.

FLEURY, A. C. C.; FLEURY, M. T. L. (1995) Aprendizagem e inovação organizacional. São Paulo: Atlas.

FREEMAN, C. (1987) Technological policy and economic performance - lessons from Japan. London: Pinter Publishers.

FRIGOTTO, G. (1995a) Os delírios da razão: crise do capital e metamorfose conceitual no campo educacional. In: Gentili, P. (Org.). Pedagogia da exclusão: crítica ao neoliberalismo na educação. Rio de Janeiro. p. 77-108. 
FRIGOTTO, G. (1995b) Educação e a crise do capitalismo real. São Paulo: Cortez.

FRIGOTTO, G. (1994) As mudanças tecnológicas e educação da classe trabalhadora: politecnia, polivalência ou qualificação profissional. In: MACHADO, L. R. S. et alli. Trabalho e educação. Campinas: Papirus. p. 45-52

FRIGOTTO, G. (1991) Tecnologia, relações sociais e educação. Tempo Brasileiro, Rio de Janeiro, n. 105, p. 131-148.

FURTADO, C. Análise do 'modelo' brasileiro. 4 ed. Rio de Janeiro: Civilização Brasileira, 1973.

GENTILI, P. (1995) 'Adeus à escola pública: a desordem neoliberal, a violência do mercado e o destino da educação das maiorias'. In: GENTILI, P. (Org.). Pedagogia da exclusão: crítica ao neoliberalismo na educação. Rio de Janeiro. p. 228-252.

GOLDMAN, S. T.; NAGEL, R.; PREISS, K. (1995) Agile competitors and virtual organizations - Strategies for Enriching the Customer. New York: Van Nostrand Reinhold.

GORANSON, T. (1995) Agile virtual enterprise: Best Agile Reference Base. Aachen Univeristy, Aachen.

GUEDES, M. D. (1999) "Qualidade total" e a educação do trabalhador na perspectiva da empresa. Dissertation (Master of Science in Education) - Federal University of São Carlos, São Carlos, Brazil.

HIRATA, H. (1994) Da polarização das qualificações ao modelo da competência. In: FERRETTI, C. et alli. (Orgs.). Novas tecnologias, trabalho e educação: um debate multidisciplinar. Petrópolis. p. 128-142.

HOFFMAN, J.; KAPLINSKY, R. (1989) Driving force: the global restructuring of technology, labor and investment in the automobile industry. Bolder Colorado: West View Press.

ISHIKAWA, K. (1986) TQC - Total Quality Control: estratégia e administração da qualidade. IMC - Internacional Sistemas Educativos.

JURAN, J.M.; GRYNA, F.M. (1988) Juran - Controle da qualidade handbook. São Paulo: McGraw Hill.

LYON, D. (1992) A sociedade da informação. Lisboa: Celta editores.

MACHADO, L. R. S. (1994a) A educação e os desafios das novas tecnologias. In: Educação e os Desafios das Novas Tecnologias. In: Ferretti, C. et alli. (Orgs.). Novas tecnologias, trabalho e educação: um debate multidisciplinar. Petrópolis. p. 165-184.

MACHADO, L. R. S. (1994b) Mudanças tecnológicas e a educação da classe trabalhadora. In: MACHADO, L. R. S. et alli. Trabalho e educação. Campinas: Papirus, 1994. p. 9-23. 
MACHADO, L. R. S. (1995) Formação geral e especializada: fim da dualidade com as transformações produtivas do capitalismo? Revista Brasileira de Educação, São Paulo, n. 0, p. 83-93, 1995.

MONTEIRO LEITE, E. (1996) El rescate de la calificación. Montevideo: Cinterfor.

PEÑA CASTRO, R. (1994). Tecnologia, trabalho e educação (indeterminações). Cadernos ANPED, n. 6.

PEÑA CASTRO, R. (1997). Contribuição ao debate da qualificação. São Carlos: UFSCar (mimeo).

PEREZ, C. (1984) Microeletrónica, ondas largas y cambio estrutural mundial: nuevas perspectivas para los países em desarollo. Sussex: The University of Sussex/ SPRU.

PIORE, M; SABEL, C. (1984) The second industrial divide: possibilities for prosperity. New York: Basic Book.

POSTHUMA, A. C. (1996) Modelos de desenvolvimento e de formação de recursos: Experiência do Brasil e da Coréia do Sul. In: WORKSHOP "MANUFATURA CLASSE MUNDIAL: MITOS E REALIDADE", 1. 1996, São Paulo. Proceedings... São Paulo: DEP/ EPUSP.

SALERNO, M. S. (1994a) Produção integrada e flexível e processo operatório: notas sobre sindicatos e a formação profissional. In: MACHADO, L. R. S. et alli. Trabalho e educação. Campinas: Papirus. p. 87-100.

SALERNO, M. S. (1994b) Trabalho e organização na empresa industrial integrada e flexível. In: FERRETTI, C. et alli. (Orgs.). Novas tecnologias, trabalho e educação: um debate multidisciplinar. Petrópolis. p. 54-76.

SANTOS FILHO, O. C. Processos de industrialização tardia: o paradigma da Coreia do Sul. Doctoral thesis. Universidade Estadual de Campinas, 1991.

SCHONBERGUER, R. (1986) Técnicas industriais japonesas. São Paulo: Pioneira.

SCHUH, G.; MILLARG, K.; GORANSSON, A. (1998) Virtuelle fabrik:neue marktchancen durch dynamische netzwerke. Munich: Wien; Hanser.

TORRES, C. A. (1995) Estado, privatização e política educacional: elementos para uma crítica do neoliberalismo. In: GENTILI, P. (Org.). Pedagogia da exclusão: crítica ao neoliberalismo na educação. Rio de Janeiro. p. 109-136

VEJA MAGAZINE (2005) 7 lições da Coréia para o Brasil. São Paulo: Abril. year 37, n. 7, February 16th. p. 60-69

WEBER, M. (1981) Os três aspectos da autoridade legítima. In: ETZIONI, A. (Org.). Organizações complexas. São Paulo: Atlas.

WOMACK, J. P.; JONES, D. T.; ROOS, D. (1992) A máquina que mudou o mundo. Rio de Janeiro: Campus. 